\title{
TANGGUNG JAWAB PERUSAHAAN DALAM PEMENUHAN JAMINAN SOSIAL KETENAGAKERJAAN DI KOTA TARAKAN
}

\author{
Darwis Manurung, Inggit Akim, Mawardi Khairi. \\ Fakultas Hukum Universitas Borneo Tarakan \\ Kalimantan Utara
}

\begin{abstract}
Social security constitutes As a part of constitutional right for every citizen as mentioned in article 28 letter h paragraph 3 of the 1945 Constitution which states that everyone is entitled to social security which enables to development dignified human being. In addition, the provisions of Article 34 paragraph 2 of the 1945 Constitution also states that the state develops social security system for all people and empower the weak and incapable in accordance with human dignity. The fulfillment of labor rights by the company is a mandate of Law Number 13 Year 2003 on Manpower Article 86 paragraph 1 which states that every worker / laborer has the right to obtain protection for safety, health, morals, morals and treatment in accordance with the dignity and human dignity and religious values.

Company policy in fulfilling labor rights on social security of labor is done through Collective Labor Agreement (PKB). In order to ensure the fulfillment of the right to social security of employment the Government of Tarakan City has issued Tarakan Mayor Instruction Number 2 Year 2014 on the Implementation of BPJS Employment Program through Licensing Administration in Tarakan City requiring employers / apprentices applying, extending permits to self-preservation and employee in BPJS Employment before the issuance of companylicensing documents. The legal consequences for non-self-employed companies and their employees in the Employment BPJS program are subject to administrative sanctions to the imposition of criminal sanctions. While the legal consequences for the workforce are not able to claim compensation to BPJS Employment if experiencing work accident, death, pension and old age pension.
\end{abstract}

Keyword: Rights of Worker, Company, Employment BPJS.

\section{PENDAHULUAN}

Tenaga kerja adalah salah satu langkah pembangunan ekonomi yang mempunyai peranan signifikan dalam segala aktivitas nasional, khususnya perekonomian nasional dalam hal peningkatan produktifitas dan kesejahteraan. Tenaga kerja yang melimpah sebagai penggerak tata kehidupan ekonomi serta merupakan sumber daya yang jumlahnya melimpah. ${ }^{1}$ Tenaga kerja adalah pelaku pembangunan dan pelaku ekonomi baik secara individu maupun secara kelompok, sehingga mempunyai peranan yang sangat signifikan dalam aktivitas perekonomian nasional yaitu meningkatkan produktifitas dan kesejahteraan masyarakat. Di Indonesia, tenaga kerja sebagai salah satu penggerak tata kehidupan ekonomi dan merupakan sumber daya yang jumlahnya

\footnotetext{
${ }^{1}$ Lalu Husni, Pengantar Hukum Ketenagakerjaan, Ed-Revisi, Raja Grafindo Persada, Jakarta, 2014, hal.47
} 
cukup melimpah. Indikasi ini bisa dilihat pada masih tingginya jumlah pengangguran di Indonesia serta rendahnya atau minimnya kesempatan kerja yang disediakan. Oleh karena itu dibutuhkannya lapangan pekerjaan yang dapat menampung seluruh tenaga kerja, tetapi tenaga kerja yang memiliki keterampilan dan keahlian yang sesuai dengan kemampuannya, sehingga tenaga kerja yang dibutuhkan dapat meningkatkan produktifitas perusahaan. ${ }^{2}$

Pada sisi lain seperti yang dikemukakan Satjipto Rahardjo bahwa untuk menggambarkan masyarakat Indonesia tidak ada yang lebih bagus dan tepat selain dengan mengatakan bahwa masyarakat itu sedang berubah secara cepat dan cukup mendasar. Indonesia adalah masyarakat yang tengah mengalami transformasi struktural yaitu dari masyarakat yang berbasis pertanian ke basis industri. Perubahan tersebut mengalami akselerasi, yaitu sejak penggunaan teknologi makin menjadi modus andalan untuk menyelesaikan permasalahan ${ }^{3}$, sehingga mobilitas tenaga kerja tidak hanya perpindahan dari desa ke kota saja hal ini bisa dimengerti karena pertumbuhan industri lebih kuat berada diperkotaan dan semakin dirasakan penghasilan yang didapat lebih memadai sehingga lebih lanjut menunjukkan adanya tenaga kerja telah melintas antar negara. Banyak hal yang mempengaruhi terjadinya migrasi antar negara, namun faktor ekonomi tetap tampak dominan. Kondisi perekonomian yang kurang menarik di negaranya sendiri dan penghasilan yang cukup besar dan yang tampak lebih menarik di negara tujuan telah menjadi pemicu terjadinya mobilitas tenaga kerja secara internasional. Pendapatan yang meningkat di negara yang sedang berkembang memungkinkan penduduk di negara berkembang untuk pergi melintas batas negara, informasi yang sudah mendunia dan kemudahan transportasi juga berperan meningkatkan mobilitas tenaga kerja secara internasional. ${ }^{4}$

Kebijakan pemerintah melalui program Jaminan Sosial Ketenagakerjaan diharapkan mampu melindungi pekerja dari aspek keselematan dan sosial. Jaminan sosial pada dasarnya merupakan hak asasi dari setiap warga negara, hal ini secara universal dijamin pada pasal 22 dan pasal 25 Deklarasi Universal Hak Asasi Manusia PBB pada tahun 1948. Berdasarkan hasil konfrensi ILO pada tahun 2002 menyebutkan bahwa jaminan sosial merupakan bentuk perlindungan yang disediakan untuk masyarakat melalui berbagai upaya dalam menghadapi kesulitan keuangan yang dapat terjadi karena kesakitan, kelahiran, pengangguran, kecacatan, usia lanjut maupun karena kematian. Jaminan sosial merupakan hal yang penting di Indonesia dan menjadi perhatian mendasar karena merupakan hak konstitusional bagi setiap warga negara sebagaimana pasal 28 huruf h ayat (3) UUD 1945 yang menyatakan bahwa setiap orang berhak atas jaminan sosial yang memungkinkan pengembangan dirinya secara utuh sebagai manusia

\footnotetext{
${ }^{2}$ Zainal Asikin, dkk, Dasar-Dasar Hukum Perburuhan, Cet 4, Raja Grafindo Persada, Jakarta, 2002, hal.76

3 Satjipto Rahardjo, Pendayagunaan Sosiologi Hukum untuk Memahami Proses-proses dalam Konteks Pembangunan dan Globalisasi, Jurnal Hukum, No. 7 Vol. 4 Tahun 1997, hal. 2.

${ }^{4}$ Aris Ananta, Liberalisasi ekspor dan impor Tenaga Kerja suatu pemikiran awal, Pusat Penelitian Kependudukan UGM, 1996, hal. 245.
} 
yang bermartabat. Kemudian pasal 34 juga menyebutkan bahwa warga negara mengembangkan sistem jaminan sosial bagi seluruh rakyat dan memberdayakan masyarakat lemah dan tidak mampu sesuai dengan martabat kemanusiaan. Pemerintah saat ini sedang menjalankan program jaminan sosial melalui Badan Pelaksana Jaminan Sosial (BPJS) yaitu BPJS Ketenagakerjaan, BPJS Kesehatan, Tabungan dan Asuransi Pegawai Negeri (Taspen) bagi pegawai negeri serta Asuransi Sosial Angkatan Bersenjata Republik Indonesia (ASABRI) bagi TNI dan POLRI. Kebijakan pemerintah melalui program ini tentu dalam rangka menjamin terpenuhinya hak-hak konstitional setiap warga negara.

Lahirnya Undang-Undang Nomor 13 Tahun 2003 tentang ketenagakerjaan merupakan sebuah terobosan baru pemerintah dalam rangka pemenuhan hak-hak buruh/pekerja. Hubungan kerja antara tenaga kerja dengan pengusaha perlu diarahkan pada terciptanya kerjasama yang serasi yang dijiwai oleh pancasila dan Undang- Undang Dasar 1945 dimana masing-masing pihak diharapkan dapat saling menghormati, saling membutuhkan, saling mengerti peranan serta hak dan kewajibannya. Salah satu bentuk hubungan pekerja dengan majikan/pengusaha adalah adanya jaminan sosial, dimana nantinya para karyawan dapat bekerja dengan aman dan sehat, artinya jauh dari ancaman - ancaman bahaya yang dapat menimbulkan gangguan bagi karyawan tersebut.Salah satu badan jaminan sosial yang dibentuk oleh pemerintah dalam memberikan jaminan sosial bagi seluruh tenaga kerja maupun karyawan di Indonesia adalah Badan Pelaksana Jaminan Sosial (BPJS) Ketenagakerjaan atau yang dahulunya disebut dengan nama PT.Jamsostek. BPJS Ketenagakerjaan ini memberikan perlindungan dasar untuk memenuhi kebutuhan minimal bagi tenaga kerja dan keluarganya dengan memberikan kepastian berlangsungnya arus penerimaan penghasilan keluarga sebagai pengganti sebagian atau seluruhnya penghasilan yang hilang akibat resiko pekerjaannya.

Berdasarkan pasal 25 Undang- Undang Nomor 23 Tahun 1992, badan penyelenggara jaminan sosial tenaga kerja adalah BUMN yang berbentuk perseroan (persero) yang dibentuk dengan peraturan perundang-undangan yang berlaku. Pada tahun 1995 PT. Jamsostek (persero) ditunjuk sebagai badan penyelenggara jaminan sosial tenaga kerja. Dalam perkembangannya pada tahun 2011, ditetapkanlah UndangUndang Nomor 24 Tahun 2011 tentang Badan Penyelenggara Jaminan Sosial, maka PT. Jamsostek berubah menjadi BPJS Ketenagakerjaan. Melalui BPJS Ketenagakerjaan diharapkan pelaksanaan sistem jaminan sosial terhadap tenaga kerja akan lebih tertata dan membantu para karyawan/tenaga kerja yang mengalami resiko terhadap kecelakaan kerja, kematian serta perubahan sosial maupun ekonomi.Salah satu hal yang membuat BPJS Ketenagakerjaan menjadi sedikit berbeda dengan PT.Jamsostek adalah perubahan dari BPJS Ketenagakerjaan yang tidak lagi berbentuk perseroan (persero) tetapi telah menjadi badan hukum publik dan tidak lagi melaksanakan program jaminan pemeliharaan kesehatan, karena seluruh program tentang jaminan kesehatan yang ada sudah ditangani oleh BPJS Kesehatan. Seluruh peserta BPJS Ketenagakerjaan secara otomatis akan ikut kedalam BPJS Kesehatan. Namun, BPJS Ketenagakerjaan tetap dipercaya menyelenggarakan program jaminan sosial tenaga kerja yang meliputi jaminan 
kecelakaan kerja (JKK), jaminan kematian (JKM), serta jaminan hari tua (JHT). Berdasarkan Peraturan Pemerintah Nomor 84 Tahun 2013 pasal 2 ayat 3 disebutkan bahwa pengusaha yang mempekerjakan tenaga kerja sebanyak 10 orang atau lebih, atau membayar upah paling sedikit Rp 1 juta sebulan, wajib mengikutsertakan tenaga kerjanya dalam program jaminan sosial tenaga kerja. Atas dasar hukum inilah maka akan timbul konsekwensi hukum bagi perusahaan-perusahaan yang belum mendaptarkan tenaga kerjanya menjadi anggota BPJS Ketenagakerjaan.

Berdasarkan uraian diatas peneliti memandang perlu melakukan penelitian tentang Tanggung Jawab Perusahaan Dalam Pemenuhan Jaminan Sosial Ketenagakerjaan di Kota Tarakan Provinsi Kalimantan Utara. Adapun rumusan masalah dalam penelitian ini, yaitu 1.) Bagaimana bentuk kebijakan perusahaan dalam pemenuhan hak tenaga kerja atas jaminan sosial ketenagakerjaan2.) Faktor yang mempengaruhi tidak terlaksananya pemenuhan hak tenaga kerja atas jaminan sosial ketenagakerjaan dan 3.) Bagaimana akibat hukum terhadap perusahaan dan tenaga kerja yang tidak terdaftar di BPJS Ketenagakerjaan

Tujuan Penelitian ini adalah untuk mendapatkan gambaran yang komprehensif mengenai bentuk-bentuk kebijakan dan upaya yang dilakukan perusahaan dalam upaya pemenuhan hak tenaga kerja atas jamsostek,menggali faktor-faktor atau hambatan yang menyebabkan tidak terpenuhinya hak tenaga kerja atas jamsostek di Kota Tarakan dan mengkaji akibat hukum terhadap perusahaan dan tenaga kerja yang tidak terdaptar di BPJS Ketenagakerjaan

\section{METODE PENELITIAN}

Jenis Penelitian ini berifat partisipatoris, yakni mengkombinasikan fungsi ganda perolehan data dan pembentukan dialog di antara pihak yang ikut ambil bagian dalam penelitian ini, bukan hanya tim peneliti pada satu pihak dan pejabat pemerintah di sisi lain, tetapi juga meliputi orang-orang kunci dengan pengetahuan dan pengalaman yang spesifik, di wilayah Kota Tarakan Provinsi Kalimantan Utara.

Data yang dikumpulkan dalam penelitian ini adalah data yang bersifat primer dan sekunder.Data primer dalam penelitian ini adalah berbagai produk hukum dan kebijakan pemerintah serta hasil wawancara dengan aktor - aktor kunci, baik dari pihak pemerintah daerah yang relevan (bupati/walikota, kepala-kepala dinas yang relevan), maupun masyarakat/perusahaan sebagai sasaran utama kebijakan pemerintah.Data sekunder berasal dari hasil penelitian kepustakaan. Data ini terdiri dari bahan hukum primer seperti peraturan perundang-undangan, bahan hukum sekunder seperti proceeding seminar, hasil penelitian sebelumnya, dokumen, buku, dan artikel yang terkait dengan judul penelitian dan bahan hukum tertier berupa kamus, ensiklopedia, brosur dan peta.

Teknik pengumpulan data yang dilakukan adalah :Studi kepustakaan, yaitu mengumpulkan data sekunder berupa bahan - bahan hukum primer, sekunder dan tersier yang erta kaitannya dengan masalah tanggung jawab perusahaan dalam pemenuhan jaminan sosial tenaga kerja. Dan Wawancara dilakukan dengan para praktisi 
yang berkaitan dengan tanggung jawab perusahaan dalam pemenuhan jaminan sosial tenaga kerja di Kota Tarakan Provinsi Kalimantan Utara

Metode analisis data yang digunakan adalah kualitatif. Metode ini menggambarkan sesuatu yang diperoleh dari teori maupun penelitian lapangan, kemudian data tersebut diseleksi dan dianalisis berdasarkan kualitas kebenarannya sehingga dapat menjawab permasalahan yang ada. Data yang telah dianalisis kemudian dibuat dalam bentuk penulisan hukum.

\section{PEMBAHASAN}

Penduduk Kota Tarakan berdasarkan proyeksi penduduk tahun 2016 sebanyak 244.185 jiwa yang terdiri atas 127.933 jiwa penduduk laki-laki dan 116.252 jiwa penduduk perempuan. Dibandingkan dengan proyeksi jumlah penduduk tahun 2015, penduduk Kota Tarakan mengalami pertumbuhan sebesar 3,66 persen dengan masingmasing persentase pertumbuhan penduduk laki-laki sebesar 3,75 persen dan penduduk perempuan sebesar 3,56 persen. Sementara itu besarnya angka rasio jenis kelamin tahun 2016 penduduk laki-laki terhadap penduduk perempuan sebesar 110,05, yang berarti bahwa di anatar 100 penduduk perempuan, terdapat 110 sampai 111 penduduk laki-laki di Kota Tarakan tahun 2016.

Jumlah penduduk usia kerja di Kota Tarakan tahun 2015 berjumlah 166.262 orang, yang terdiri dari 104.368 orang angkatan kerja dan 61.894 orang bukan angkatan kerja. Tingkat partisipasi angkatan kerja di Kota Tarakan tahun 2015 mencapai angka 62,77 persen dan tingkat pengangguran di Kota Tarakan pada tahun 2015 adalah 5,60 persen (5,29 persen laki-laki dan 6,33 persen perempuan).

pendidikan tertinggi yang ditamatkan, Angkatan Kerja di Kota Tarakan tahun 2015 dengan tingkat pendidikan tertinggi yang ditamatkan adalah Sekolah Menengah Atas sebesar 27,96 persen dan 0,66 persen adalah angkatan kerja dengan tingkat pendidikan adalah tidak/belum pernah sekolah.

Berdasarkan kelompok umur, sebesar 27,35 persen penduduk berumur 15 tahun ke atas yang bekerja selama seminggu yang lalu di Kota Tarakan tahun 2015 berada pada kelompok umur 35 -44 tahun, dan masih ada penduduk usia 65 tahun ke atas yang bekerja selama seminggu yang lalu (2,29 persen). Sebesar 61,46 persen penduduk berumur 15 tahun ke atas yang bekerja selama seminggu yang lalu di Kota Tarakan tahun 2015 berstatus sebagai buruh/ karyawan/ pegawai, dan sebesar 2,43 persen berstatus sebagai pekerja bebas.

Terkait dengan jumlah sampel Survei Angkatan Kerja Nasional (Sakernas) Agustus 2016 yang merupakan sumber data indikator ketenagakerjaan tahun 2016 yang hanya mencakup 5.000 blok sensus atau sekitar 50.000 rumah tangga, maka BPS hanya dapat menyajikan data ketenagakerjaan pada tingkat nasional dan provinsi, sehingga data terbaru terkait dengan indikator ketenagakerjaan adalah data tahun 2015. 
Jumlah Pencari Kerja Terdaftar di Kota Tarakan pada Dinas Ketenagakerjaan dan Perindustrian Kota Tarakan pada Tahun 2016 sebesar 2.916 orang dengan peningkatan sebesar 20,05 persen bila dibandingkan dengan tahun 2015. Dari 2.916 orang yang terdaftar sebanyak 613 orang telah ditempatkan bekerja (357 laki-laki dan 256 perempuan). Pada tahun 2016, Proporsi terbesar pencari kerja yang mendaftar pada Dinas Ketenagakerjaan Dan Perindustrian Kota Tarakan tahun berpendidikan terakhir SMA yaitu sebesar 62,21 persen (1.814 orang) dan yang ditempatkan sebanyak 613 orang.

Jumlah Penduduk Berumur 15 Tahun Ke atas yang Bekerja selama seminggu Menurut Status Pekerjaan Utama dan jenis Kelamin di Kota Tarakan.

Tabel. 1.2

\begin{tabular}{lccc}
\hline & & \multicolumn{3}{c}{ Jenis Kelamin/Sex } \\
\cline { 2 - 4 } $\begin{array}{l}\text { Status Pekerjaan Utama } \\
\text { Main Employment Status }\end{array}$ & $\begin{array}{l}\text { Laki-laki } \\
\text { Male }\end{array}$ & $\begin{array}{l}\text { Perempuan } \\
\text { Female }\end{array}$ & $\begin{array}{l}\text { Jumlah } \\
\text { Total }\end{array}$ \\
\hline \multicolumn{1}{c}{$(1)$} & $(2)$ & $(3)$ & $\mathbf{( 4 )}$ \\
1. Berusaha Sendiri & 11776 & 5478 & $\mathbf{1 7 2 5 4}$ \\
2. Berusaha dibantu buruh & 5268 & 705 & $\mathbf{5 9 7 3}$ \\
$\begin{array}{l}\text { tidak tetap/tak dibayar } \\
\text { 3. Berusaha dibantu buruh } \\
\text { tetap/buruh dibayar }\end{array}$ & 6413 & 799 & $\mathbf{7 2 1 2}$ \\
4. Buruh/Karyawan/Pega & 42140 & 18415 & $\mathbf{6 0 5 5 5}$ \\
wai & 1968 & 428 & $\mathbf{2 3 9 6}$ \\
$\begin{array}{l}\text { 5. Pekerja bebas } \\
\text { 6. Pekerja Keluarga/tidak }\end{array}$ & 2349 & 2788 & $\mathbf{5 1 3 7}$ \\
dibayar & & & $\mathbf{9 8 5 2 7}$ \\
\hline \hline
\end{tabular}

Sumber: Dinas Penanaman Modal dan Pelayanan Terpadu Satu Pintu Kota Tarakan

Pada tahun 2016, jumlah perusahaan kecil dan menengah di Kota Tarakan adalah 530 perusahaan dengan jumlah tenaga kerja sebanyak 2.271 orang. Bila dilihat berdasarkan klasifikasi industri, dari 530 perusahaan kecil dan menengah yang ada di Kota Tarakan pada tahun 2016, 9,62 persen adalah perusahaan kecil dan menengah untuk klasifikasi industri sandang; 6,98 persen adalah mebel; 18,49 persen adalah pangan; 13,02 persen adalah kimia dan bahan bangunan; 6,04 persen adalah hasil hutan; 41,70 persen adalah logam dan elektronika; serta 4,15 persen adalah kerajinan.

Pada tahun 2016, terdapat 705 perusahaan di Kota Tarakan yang tercatat badan hukumnya di Dinas Penanaman Modal dan Pelayanan Terpadu Satu Pintu Kota Tarakan. Dari 705 perusahaan tersebut, bila dirinci menurut tipe badan hukumnya, maka 196 adalah perusahaan dengan badan hukum perseroan terbatas, 244 firma, 8 perusahaan 
dengan tipe badan hukum adalah koperasi, 256 PO, dan 1 perusahaan dengan tipe badan hukum BUL.

Tahun 2016, terdapat 146 koperasi di Kota Tarakan yang tersebar di masingmasing kecamatan yang ada di Kota Tarakan. 34,25 persen koperasi tersebut (50 koperasi) berada di Kecamatan Tarakan Tengah, 33,56 persen (49 koperasi) berada di Kecamatan Tarakan Barat, 21,23 persen (31 koperasi) di Kecamatan Tarakan Timur, dan 10,96 persen berada di Kecamatan Tarakan Utara.

Jumlah Perusahaan Menurut Bentuk Badan Hukum di Kota Tarakan, 2012-2016

Tabel. 1.3

\begin{tabular}{llllll}
\hline \hline Tipe Badan Hukum & \multicolumn{1}{c}{$(1)$} & \multicolumn{1}{c}{2013} & 2014 & 2015 & 2016 \\
\hline Perseroan terbatas & \multicolumn{1}{c}{$(2)$} & $(3)$ & $(4)$ & $(6)$ & $(7)$ \\
CV/Firma & 133 & - & 150 & 205 & 196 \\
Koperasi & 266 & - & 350 & 282 & 244 \\
FA & 16 & - & 5 & 16 & 8 \\
PO & 0 & - & 0 & 1 & 0 \\
BUL & 262 & - & 187 & 380 & 256 \\
\hline Jumlah & 3 & - & 4 & 4 & 1 \\
\hline \hline
\end{tabular}

Sumber: Dinas Penanaman Modal dan Pelayanan Terpadu Satu Pintu Kota Tarakan

\section{A. Bentuk kebijakan perusahaan dalam pemenuhan hak tenaga kerja atas Jaminan Sosial Ketenagakerjaan}

Meningkatnya peranan tenaga kerja dalam perkembangan pembangunan nasional di seluruh Indonesia dan penggunaan teknologi diberbagai sektor kegiatan usaha dapat mengakibatkan semakin tinggi resiko yang mengancam keselamatan, kesehatan dan kesejahteraan tenaga kerja sehingga perlu adanya peningkatan perlindungan tenaga kerja. Perlindungan tenaga kerja juga dilakukan oleh pekerja yang melakukan pekerjaan baik dalam hubungan kerja maupun diluar hubungan kerja melalui progam Jaminan Sosial Tenaga Kerja (Jamsostek) dimana pada 1 Januari 2014 Jamsostek telah di ubah menjadi BPJS Ketenagakerjaan yang beroperasi mulai Juli Tahun 2015.

BPJS Ketenagakerjaan merupakan badan penyelenggara Jaminan Sosial yang berbentuk badan hukum publik yang dibentuk berdasarkan Undang-Undang Nomor 24 Tahun 2011 tentang BPJS yang bertanggung jawab lang s u $\mathrm{g}$ kepada presiden dan berfungsi menyelenggarakan progam jaminan kecelakaan kerja, jaminan hari tua, jaminan pensiun dan jaminan kematian berdasarkan ketentuan Undang-Undang Nomor 40 Tahun 2004 tentang Sistem Jaminan Sosoal Nasional disingkat UU SJSN bagi seluruh pekerja di Indonesia. 
Perlindungan terhadap hak pekerja bersumber pada Pasal 27 ayat (2) UUD 1945, yaitu tiap-tiap warga negara berhak atas pekerjaan dan penghidupan yang layak bagi kemanusiaan. Selain itu jaminan perlindungan atas pekerjaan dituangkan pula dalam dalam ketentuan Pasal 28 D ayat (1) UUD 1945, yaitu Setiap orang berhak atas pengakuan, jaminan, perlindungan dan kepastian hukum yang adil serta perlakuan yang sama dihadapan hukum. Pasal 28 ayat (2), yaitu setiap orang berhak untuk bekerja serta mendapat imbalan dan perlakuan yang adil dan layak dalam hubungan kerja. Ketentuan tersebut menunjukan bahwa di Indonesia hak untuk bekerja telah memperoleh tempat penting dan dilindungi oleh UUD 1945.

UUD 1945 Pasal 28 H (amandemen kedua) menyatakan bahwa setiap orang berhak atas jaminan sosial yang memungkinkan pengembangan dirinya secara utuh sebagaimana manusia yang bermartabat dan Pasal 34 ayat 2 (amandemen keempat) menyatakan bahwa negara mengembangkan sistem jaminan sosial bagi seluruh rakyat dan memberdayakan masyarakat yang lemah dan tidak mampu sesuai dengan martabat kemanusiaan.

Undang - Undang Nomor 13 Tahun 2003 tentang Ketenagakerjaan selanjutnya disingkat UU Ketenagakerjaan. Berdasarkan ketentuan Pasal 99 ayat 1 menyebutkan bahwa setiap pekerja/buruh dan keluarganya berhak untuk memperoleh jaminan sosial tenaga kerja dan pada ayat 2 menyebutkan jaminan sosial tenaga kerja sebagaimana dimaksud dalam ayat (1) dilaksanakan sesuai dengan peraturan perundang-undangan yang berlaku. Program jaminan sosial ketenagakerjaan ditujukan dalam rangka memberikan kepastian keberlangsungan penghasilan pekerja sebagai pengganti sebagian atau keseluruhan penghasilan yang hilang yang di akibatkan terjadinya kecelakaan kerja.

Pemenuhan hak-hak pekerja haruslah sesuai dengan peraturan yang berlaku dan pengusaha tidak dapat melakukan kesewenang-wenangan terhadap pekerjanya. Pemenuhan hak tersebut antara lain tentang upah yang harus sesuai dengan upah minimum daerah setempat, tentang jaminan sosial ketenagakerjaan yang telah diatur dibeberapa peraturan perundang-undangan, tunjangan-tunjangan dan pemenuhan hakhak pekerja lain yang terdapat dalam UU Ketenagakerjaan. Program jaminan sosial ketenagakerjaan merupakan hak setiap tenaga kerja, baik dalam hubungan kerja maupun tenaga kerja luar hubungan kerja.

Undang -Undang Sistem Jaminan Sosial Nasional (UU SJSN ) menyebutkan bahwa pemberi kerja secara bertahap wajib mendaftarkan dirinya dan pekerjanya sebagai peserta kepada Badan Penyelenggara Jaminan Sosial, sesuai dengan program jaminan sosial yang diikuti. Istilah pekerja yang dimaksud adalah Pasal 1 angka 11 UU SJSN setiap orang yang bekerja menerima gaji, upah atau imbalan dalam bentuk lain. Sedangkan pemberi kerja yang dimaksud di sini adalah orang perseorangan, pengusaha, badan hokum atau badan-badan lainnya yang mempekerjakan tenaga kerja atau penyelenggara 
negara yang mempekerjakan pegawai negeri dengan membayar gaji, upah atau imbalan dalam bentuk lainnya sesuai Pasal 1 angka 12 UU SJSN.

Ketentuan Pasal 1 Angka 5 UU Ketenagakerjaan mendefenisikan pengusaha adalah:

a. orang perseorangan, persekutuan, atau badan hukum yang menjalankan suatu perusahaan milik sendiri;

b. orang perseorangan, persekutuan, atau badan hukum yang secara berdiri sendiri menjalankan perusahaan bukan miliknya;

c. orang perseorangan, persekutuan, atau badan hukum yang berada di Indonesia mewakili perusahaan sebagaimana dimaksud dalam huruf a dan b yang berkedudukan di luar wilayah Indonesia.

Badan Penyelenggara Jaminan Sosial Ketenagakerjaan selanjutnya disingkat BPJS Ketenagakerjaan merupakan program publik yang memberikan perlindungan bagi tenaga kerja untuk mengatasi risiko sosial ekonomi tertentu dan penyelenggaraannya menggunakan mekanisme asuransi sosial. Sebagai lembaga negara yang bergerak dalam bidang asuransi social, BPJS Ketenagakerjaan yang dahulu bernama PT Jamsostek (Persero) merupakan pelaksana Undang-Undang Jaminan Sosial Ketenagakerjaan.

BPJS Kesehatan dahulu bernama Askes bersama BPJS Ketenagakerjaan merupakan program pemerintah dalam kesatuan Jaminan Kesehatan Nasional (JKN) yang diresmikan pada tanggal 31 Desember 2013. Untuk BPJS Kesehatan mulai beroperasi sejak tanggal 1 Januari 2014, sedangkan BPJS Ketenagakerjaan mulai beroperasi sejak 1 Juli 2015.

UU BPJS. Pasal 5 Ayat 2 UU BPJS ini dibentuk 2 (dua) Badan Penyelenggara Jaminan Sosial disingkat BPJS, yaitu BPJS Kesehatan dan BPJS Ketenagakerjaan. BPJS Kesehatan menyelenggarakan program jaminan kesehatan dan BPJS Ketenagakerjaan menyelenggarakan program jaminan kecelakaan kerja, jaminan hari tua, jaminan pensiun, dan jaminan kematian (sebagaimana diatur dalam Pasal 2 Ayat 2 UU BPJS).

Pada prinsipnya, setiap orang termasuk orang asing yang bekerja paling singkat 6 (enam) bulan di Indonesia, wajib menjadi Peserta program Jaminan Sosial. BPJS Ketenagakerjaan merupakan hasil akumulasi berbagai Undang-Undang (UU) dan peraturan yang berfokus pada jaminan sosial dan perlindungan ketenagakerjaan di Indonesia. perlindungan dan jaminan sosial ketenagakerjaan merupakan tanggung jawab negara dan sudah diperjuangkan pekerja atau buruh. Perlu diketahui, sebelum BPJS kesehatan terbentuk, masalah perlindungan dan jaminan sosial ketenagakerjaan Indonesia itu dilaksanakan oleh PT Jaminan Sosial Tenaga Kerja (Jamsostek) berdasarkan Undang-Uundang Nomor 3 Tahun 1992 tentang Jaminan Sosial tenaga Kerja. PT Jamsostek akhirnya bertransformasi menjadi BPJS Ketenagakerjaan yang bertanggung jawab langsung ke presiden berdasarkan mandat dari UU BPJS. 
Maka untuk memenuhi hak dari pekerja pemerintah melalui Program jaminan sosial ketenagakerjaan mewajibankan setiap perusahaan (pemberi kerja) sebagaimana di atur dalam Pasal 15 ayat 1 UU BPJS yang menyatakan bahwa Pemberi Kerja secara bertahap wajib mendaftarkan dirinya dan Pekerjanya sebagai Peserta kepada BPJS sesuai dengan program Jaminan Sosial yang diikuti.

Perlindungan, pemeliharaan dan peningkatan kesejahteraan yang berbentuk program jaminan sosial ketenagakerjaan dicanangkan oleh pemerintah dan wajib dilaksanakan oleh pengusaha, apabila dalam pelaksanaannya telah memenuhi persyaratan yang telah di tentukan yaitu mempunyai pekerja sebanyak 10 (sepuluh) orang atau lebih dan juga mengeluarkan uang untuk menggaji pekerjanya sebesar 1.000.000 rupiah untuk setiap bulannya. Pada dasarnya program jaminan sosial ketenagakerjaan ini menekankna pada perlindungan bagi tenaga kerja yang relatif mempunyai kedudukan yang lebih lemah.Oleh karena itu pengusaha memikul tanggung jawab utama dan secara moral pengusaha mempunyai kewajiban untuk menungkatkan perlindungan dan kesejahteraan tenaga kerja.

BPJS Ketenagakerjaan sebagaimana dimaksud dalam Pasal 5 ayat (2) huruf b menyelenggarakan program adalah sebagai berikut:

1. Jaminan Kecelakaan Kerja (JKK)

JKK akan memberikan kompensasi dan rehabilitasi bagi tenaga kerja yang mengalami kecelakaan pada saat mulai berangkat kerja sampai kembali ke rumah atau menderita penyakit akibat hubungan kerja. Iuran untuk JKK ini dibayarkan sepenuhnya oleh perusahaan, yang nilainya 0,24 persen hingga 1,74 persen sesuai dengan kelompok usaha.

2. Jaminan Hari Tua (JHT)

Untuk program JHT, perusahaan akan menanggung sebanyak 3.7 persen dari total iurannya. Peserta akan mendapatkan semua iuran yang dikumpulkan tersebut setelah memasuki masa pensiun, yaitu saat berumur 55 tahun. Jumlah total klaim iuran itu biasanya lebih besar karena sebelumnya BPJS Ketenagakerjaan menginvestasikan dana iuran perserta tersebut, sehingga peserta mendapatkan keuntungan yang cukup lumayan. Untuk peserta yang meninggal atau cacat permanen juga tetap mendapat klaim iuran tersebut.

3. Jaminan Pensiun

Jaminan pensiun adalah jaminan sosial yang bertujuan untuk mempertahankan derajat kehidupan yang layak bagi peserta dan/atau ahli warisnya dengan memberikan penghasilan setelah peserta memasuki usia pensiun, mengalami cacat total tetap, atau meninggal dunia.

Manfaat pensiun adalah sejumlah uang yang dibayarkan setiap bulan kepada peserta yang memasuki usia pensiun, mengalami cacat total tetap, atau kepada ahli waris bagi peserta yang meninggal dunia 
4. Jaminan Kematian (JK)

Jumlah jaminan yang akan diberikan adalah Rp 21 juta. Uang tersebut terdiri dari santunan kematian sebesar Rp 14 juta dan biaya pemakanan Rp 2 juta dan santunan berkala. Program ini menjamin kematian yang bukan karena kecelakaan kerja. Yang mendapatkan jaminan ini adalah ahli waris dari pegawai tersebut.

Berikut ini jumlah perusahaan dan tenaga kerja yang ada di Kota Tarakan Tahun 2017 sebagai berikut:

Tabel.1.4

\begin{tabular}{|c|c|c|c|}
\hline \multirow{6}{*}{ Sumber: } & Klasifikasi Perusahaan & $\begin{array}{c}\text { Jml } \\
\text { Perusahaan }\end{array}$ & $\begin{array}{c}\text { Jumlah } \\
\text { Tenaga } \\
\text { Kerja }\end{array}$ \\
\hline & (1) & (2) & (3) \\
\hline & BESAR & 46 & 15072 \\
\hline & SEDANG & 38 & 2616 \\
\hline & KECIL & 209 & 3253 \\
\hline & Jumlah & 293 & 20941 \\
\hline
\end{tabular}

\section{Perindustrian dan Tenaga Kerja Kota Tarakan}

Berikut jumlah perusahaan yang telah mendaptar dan belum mendaptar BPJS Ketenagakerjaan Kota Tarakan Tahun 2017 sebagai berikut:

Tabel 1.5

\begin{tabular}{lccc} 
Sumber: & \multicolumn{1}{c}{$\begin{array}{c}\text { Klasifikasi } \\
\text { Perusahaan }\end{array}$} & Mendaptar & $\begin{array}{c}\text { Belum } \\
\text { Mendaptar }\end{array}$ \\
\cline { 2 - 4 } & $(1)$ & $(2)$ & $(3)$ \\
\cline { 2 - 2 } & 6 & 39 \\
SEDANG & 13 & 32 \\
KECIL & & 196 \\
& & 26 & 267 \\
\hline
\end{tabular}

\section{Ketenagakerjaan Kota Tarakan}

Berdasarkan data diatas mengammbarkan bahwa 9\% perusahaan yang ada di Kota Tarakan sudah mendaptarkan perusahaan dan tenaga kerjanya dalam program jaminan sosial ketenagakerjaan. 
Sedangkan jumlah tenaga kerja yang belum dan sudah di daptarkan program BPJS Keteneagakerjaan dimasing-masing kategori sebagai berikut:

Tabel 1.6

\begin{tabular}{lccc} 
Sumber: & Klasifikasi & TK & TK \\
Perusahaan & Terdaptar & $\begin{array}{c}\text { Belum } \\
\text { Terdaptar }\end{array}$ \\
& $(1)$ & $(2)$ & $(3)$ \\
\hline BESAR & 6156 & 8916 \\
SEDANG & 407 & 2209 \\
KECIL & 224 & 3029 \\
\hline Jumlah & & 6787 & 14154
\end{tabular}

\section{Ketenagakerjaan Kota Tarakan}

Berdasarkan hasil penelitian menggambarkan bahwa 9\% perusahaan di Kota Tarakan sudah mendaptarkan perusahaan dan tenaga kerjanya dalam program BPJS Ketenagakerjaan sehingga ketentuan pasal 15 ayat 1 Undang-Undang Nomor 24 Tahun 2011 tentang Badan Penyelenggaran Jaminan Sosial yang menyatakan bahwa Pemberi Kerja secara bertahap wajib mendaftarkan dirinya dan Pekerjanya sebagai Peserta kepada BPJS sesuai dengan program Jaminan Sosial yang diikuti sudah terlaksana .

Sebagai perbandingan berikut kami cantumkan jumlah pemberi kerja/perusahaan yang sudah mendaptar diri dan pekerjanya pada program BPJS Ketenagakerjaan sebagai berikut:

Tabel 1.7

\begin{tabular}{lccc}
\hline \hline & Klasifikasi & Jumlh & Jumlah \\
& Perusahaan & & TK \\
& $(1)$ & $(2)$ & $(3)$ \\
& & & \\
\hline BESAR & 7 & 9028 \\
SEDANG & 6 & 4093 \\
KECIL & 13 & 2766 \\
& & \\
\hline Jumlah & 26 & 15.887
\end{tabular}

\section{Sumber: BPJS Ketenagakerjaan Kota Tarakan}


Adapun kepesertaan BPJS Ketenagakerjaan dibagi menjadi 4 kategori kepesertaan yaitu : 5

1. Perusahaan yang belum sama sekali mendaptarkan tenaga kerjanya

2. Perusahaan sudah mendaptarkan semua tenaga kerjanya sesuai upah

3. Perusahaan yang mendaptarkan sebagian tenaga kerja dan sebagian upah

4. Perusahaan yang tidak membayarkan iuran tenaga kerja (menunggak)

Upaya BPJS Ketenagakerjaan untuk meningkatkan partisipasi perusahaan untuk mendaptarkan tenaga kerjanya melalui bagian pemasaran BPJS Ketenagakerjaan secara persuasif meminta perusahaan untuk mendaptarkan tenaga kerjanya dengan berkirim surat ke perusahaan sebanyak du kali. Apabila tidak ada respon dari perusahaan maka akan dilakukan pemanggilan kepada pihak perusahaan untuk dilakukan pemeriksaan oleh bagian pemeriksaan dan jika berdasarkan surat pemanggilan tetap tidak di indahkan tanpa adanya keterangan maka maka diterbitkanlah surat ketidakpatuhan yang dikirimkan ke perusahaan dengan tembusannya ke kejaksaan,KPPN, Pengawas Ketenagakerjaan, Imigrasi, Kantor Pelayanan Perizinan Terpadu) untuk dilakukan penindakan kepada perusahaan yang tidak mentaati perintah undang-undang dalam hal ini dilakukan oleh Penyidik Kejari dan Pengawas Ketenagakerjaan (penyidik PNS).

Kepesertaan Perusahaan (Pemberi Kerja) BPJS Ketenagakerjaan di kategorikan menjadi dua yaitu :

1. Perusahaan/usaha kecil-mikro yang modal 0-500.000.000 surat izin usahanya dari kecamatan

2. Perusahaan/usaha menengah-besar yang modalnya 500.000 .00 ke atas surat izin usahanya diterbitkan oleh Dinas Penanaman Modal dan Pelayanan Terpadu Satu Pintu

Adapun program BPJS Ketenagakerjaan yang harus di ikuti oleh peserta (perusahaan/pemberi kerja) adalah sebagai berikut :

1. Untuk usaha kecil-mikro mengikuti program Jaminan Kecelakaan Kerja dan Jaminan Kematian.

2. Untuk usaha sedang mengikuti program Jaminan Kecelakaan Kerja,Jaminan Kematian dan Jaminan Hari Tua.

3. Untuk perusahaan besar mengikuti program Jaminan Kecelakaan Kerja, Jaminan Kematian, Jaminan Hari Tua dan Jaminan Pensiun.

Pelaksanaan program Jaminan Sosial Ketenagakerjaan berdasarkan UndangUndang Nomor 24 tahun 2011 telah dilaksanakan oleh perusahaan di Kota Tarakan, hal ini dapat dilihat dalam Perjanjian Kerja Bersama yang selanjutnya disingkat PKB, yang mana perusahaan mengikutsertakan seluruh pekerja dalam program BPJS Ketenagakerjaan. PKB adalah perjanjian yang merupakan hasil perundingan antara

\footnotetext{
${ }^{5}$ Wawancara pada tanggal 16 Oktober 2017 dengan Sri Wulandari (Petugas Pemeriksa Cabang BPJS Ketenagakerjaan Tarakan)
} 
serikat pekerja yang tercatat pada instansi yang bertanggungjawab dibidang ketenagakerjaan dengan pengusaha atau beberapa pengusaha atau perkumpulan penguasa yang memuat syarat-syarat kerja, hak, dan kewajiban kedua belah pihak. Selain itu, Pemerintah Kota Tarakan telah menerbitkan Instruksi Walikota Tarakan Nomor 2 Tahun 2014 Tentang Penyelenggaraan Program BPJS Ketenagakerjaan Melalui Administrasi Perizinan di Kota Tarakan yang mempersyaratkan kepada pemberi kerja/pengusaha yang melakukan pengajuan, perpanjangan perizinan untuk mendaptarkan diri dan pekerjanya dalam BPJS Ketenagakerjaan sebelum diterbitkankannya dokumen perizinan perusahaan. Hal ini merupakan salah satu kebijakan pemerintah dalam pemenuhan hak atas jaminan sosial ketenagakerjaan bagi pekerja yang ada di Kota Tarakan.

\section{B. FAKTOR FAKTOR YANG MEMPENGARUHI TIDAK TERLAKSANANYA PEMENUHAN HAK TENAGA KERJA ATAS JAMIANAN SOSIAL KETENAGAKERJAAN}

Jaminan sosial ketenagakerjaan adalah hak bagi setiap pekerja di Indonesia. Hak-hak pekerja dalam memperoleh jaminan sosial ketenagakerjaan sudah didukung dengan adanya Undang-Undang yang mengatur terkait jaminan sosial ketenagakerjaan, salah satunya adalah Pasal 13 ayat (1) Undang-Undang Nomor 40 Tahun 2004 tentang Sistem Jaminan Sosial Nasional, yang menyatakan bahwa Pemberi kerja secara bertahap wajib mendaftarkan dirinya dan pekerjaannya sebagai peserta kepada Badan Penyelenggara Jaminan Sosial sesuai dengan program jaminan sosial yang diikuti. Kebijakan-kebijakan yang dijalankan oleh pemerintah terkait dengan ketenagakerjaan bertujuan untuk meningkatkan kesejahteraan para pekerja/buruh dengan berbagai upaya diantaranya perbaikan upah, jaminan sosial, perbaikan kondisi kerja, dalam hal ini untuk meningkatkan kedudukan harkat dan martabat tenaga kerja.

Penyelenggaraan program jaminan sosial merupakan salah satu tanggung jawab dan kewajiban Negara dalam memberikan perlindungan sosial ekonomi kepada masyarakat demi terciptanya kemanusiaan yang adil dan beradab serta keadilan sosial bagi seluruh rakyat Indonesia. Selain diamanatkan dalam pancasila, mengenai kewajiban Negara menyelenggarakan program jaminan sosial juga tersurat dalamPasal 28 H dan Pasal 34 UUD 1945 yang menyatakan Negara wajib memberikan kepastian perlindungan dan kesejahteraan sosial terhadap seluruh rakyat Indonesia. Jaminan sosial merupakan bentuk pelayanan pemerintah kepada masyarakat sesuai dengan kemampuan negara demi memberikan keringanan bagi masyarakat dari segi ekonomi serta tepat guna melalui badan atau organisasi. Sejalan dengan hal ini, maka pemerintah memandang perlu adanya alat yang berbentuk organisasi atau badan khusus yang menangani jaminan sosial.

Ketentuan mengenai kewajiban pemberi kerja mendaftarkan pekerjanya sebagai peserta BPJS Ketenagakerjaan pada tataran implementasi masih menghadapi hambatan khususnya dari sisi pemberi kerja atau perusahaan yang memiliki kewajiban untuk mendaftarkan dirinya dan pekerjanya pada program BPJS Ketenagakerjaan.Perusahaan yang tidak mengikut sertakan pekerjanya dalam program BPJS Ketenagakerjaan dan mengalamai keterlambatan dalam membayarkan iuran dapat merugikan pekerja dimana 
pekerja tidak mempunyai kekuatan dalam menuntut hak-haknya. Seharusnya dengan telah dibuatnya peraturan hukum yang mengikat, pemberi kerja mampu melaksanakan apa yang menjadi kewajibannya dalam memberikan hak-hak pekerja sesuai dengan ketentuan yang berlaku.

Berdasarkan hasil wawancara yang dilakukan kepada pihak BPJS Ketenagakerjaan, pihak BPJS Ketenagakerjaan menyatakan bahwa ada beberapa factor yang menyebabkan perusahaan/pemberi kerja tidak tidak mengikut sertakan diri dan pekerjanya dalam program jaminan sosial ketenagakerjaan antara lain sebagai berikut: 6

1. Usaha Kecil/Usaha Masih Kecil

Perusahaan yang ada di Kota Tarakan tidak semuanya tergolong perusahaan lama atau besar.Ada juga sebagian perusahaan dalam hal ini (CV,PT,UD,PO) yang sifanya baru memulai menjalankan usaha,sehingga merasakan beratnya ketika harus membayar iuran bulanan BPJS Ketenagakerjaan bagi tenaga kerjanya dengan alasan keuangan perusahaan hanya mencukupi sebagai modal,biaya operasional dan gaji pokok pekerja saja.Berdasarkan hasil wawancara dengan Fanny perwakilan PT.Patria Jaya Mandiri menyatakan bahwa pekerja belum di asuransikan karena masih baru berdiri sehingga kas perusahaan belum memenuhi. $^{7}$

2. Telah Ikut Asusransi Swasta dan BPJS Kesehatan

Adanya perusahaan asusransi swasta menjadi salah satu alasan sebagian perusahaan (pemberi kerja) tidak mendaptarkan diri dan pekerjanya ke program BPJS Ketenagakerjaan karena pemberi kerja sudah mengasuransikan usahanya dan pegawainya di asuransi swasta dan pegawainya juga sudah mengikuti program BPJS Kesehatan individual dan bahkan ada pekerja yang mendapatkan Kartu Indonesia Sehat (KIS) yang merupakan program pemerintah bagi masyarakat tidak mampu sehingga atas dasar ini pemberi kerja tidak mengikuti program BPJS Ketenagakerjaan. Menurut Alex Johansyah Putra menyatakan bahwa semua pekerja sudah di asuransikan oleh perusahaan ${ }^{8}$ Disamping itu menurut Maudya Nabili menyatakan bahwa perusahaan kami sendiri menyelenggarakan usaha kegiatan asuransi jiwa sehingga pekerja sudah otomatis di asuransikan ${ }^{9}$

3. Kurang Pemahaman Tentang BPJS Kesehatan dan Ketenagakerjaan

Perusahaan (Pemberi Kerja) memiliki persepsi yang berbeda dalam hal asuransi bagi buruh atau pekerja ,bagi perusahaan bahwa apabila pekerja sudah mendaptar di BPJS Kesehatan maka pekerja tersebut tidak perlu mendaptar lagi di BPJS Ketenagakerjaan hal ini juga karena perusahaan sudah mengasurnasikan pekerjanya di asuransi swasta.

\footnotetext{
${ }^{6}$ Wawancara pada tanggal 16 Oktober 2017 dengan Sri Wulandari selaku Petugas Pemeriksa Cabang BPJS Ketenagakerjaan Kota Tarakan

${ }^{7}$ Wawawncara Fanny tanggal 9 November 2017 dari PT.Patria Jaya Mandiri

${ }^{8}$ Wawancara Alex Johansyah Putra tanggal 4 November 2017 selaku Unit Manager PT.Asuransi Jiwasraya Cabang Tarakan

${ }^{9}$ Wawancara Maudya Nabila pada tanggal 12 November 2017 selaku Admin PT.Prudential
} 


\section{Pekerja Tidak Tetap/ Kontrak}

Dalam pelaksanaan kegiatan usaha dalam perusahaan tentu ada pekerja tetap,kontrak bahkan outsorsing. Adanya perjanjian sebagai pekerja tetap,kontrak maupun oustsorsing memiliki konsekwensi dalam hal pemenuhan hak-hak pekerja. Perusahaan (CV, PT, UD, PO) yang memiliki pekerja terkadang hanya sebentar dan mengundurkan diri sebelum kontrak selesai sehingga tidak bisa di daptarkan ke program BPJS Ketenagakerjaan.

\section{AKIBAT HUKUM TERHADAP PERUSAHAAN DAN PEKERJA YANG TIDAK TERDAFTAR DI BPJS KETENAGAKERJAAN}

Pekerja juga merupakan salah satu kompenen penting dalam suatu perusahaan, seorang pekerja akan dapat bekerja dengan baik apabila pekerja tersebut merasa aman, nyaman, dan terlindungi pekerjaannya. Maka dari itu, pemerintah menyediakan program-program jaminan sosial ketenagakerjaan yang juga merupakan wujud kehadiran pemerintah dalam mensejahterakan rakyat. Untuk memaksimalkan fasilitas yang diberikan, pemerintah juga mengadakan sosialisasi kepada pekerja terkait program-program yang terdapat di jaminan sosial ketenagakerjaan yang dikelola oleh BPJS Ketenagakerjaan dalam hal ini yang mempunyai kewenangan adalah Dinas Perindustrian Dan Ketenagakerjaan yang ada di Kota Tarakan. ${ }^{10}$

Badan Penyelenggara Jaminan Sosial (BPJS) Ketenagakerjaan merupakan sebuah lembaga hukum nirlaba untuk perlindungan sosial dalam menjamin seluruh rakyat agar dapat memenuhi kebutuhan dasar hidup yang layak sekaligus dibentuk untuk menjalankan program jaminan sosial di Indonesia. Tujuan dari BPJS Ketenagakerjaan adalah untuk memberikan perlindungan terhadap pekerja, yang berarti suatu kewajiban bagi pengusaha atau perusahaan untuk mengikutsertakan pekerja dalam program program BPJS, seperti jaminan kecelakaan kerja, jaminan kematian, jaminan hari tua dan jaminan pemeliharaan kesehatan.

Perusahaan berkepentingan secara langsung dengan kesejahteraan pekerja dan keluarganya. Oleh karena itu, perusahaan wajib mensejahterakan pekerja dan keluarganya. Salah satu cara untuk meringankan beban pihak pengusaha dalam melaksanakan kewajiban untuk memberikan tunjangan kecelakaan, pemeliharaan kesehatan dan jaminan di hari tua bagi para pekerja adalah dengan kebijakan para pengusaha mengikutsertakan pekerja di perusahaan dalam program BPJS Ketenagakerjaan. UU BPJS, secara tegas menyatakan bahwa BPJS yang dibentuk dengan UU BPJS adalah badan hukum publik. BPJS yang dibentuk dengan UU BPJS adalah BPJS Kesehatan dan BPJS Ketenagakerjaan. Kedua BPJS tersebut pada dasarnya mengemban misi negara untuk memenuhi hak konstitusional setiap orang atas jaminan sosial dengan menyelenggarakan program jaminan yang bertujuan memberi kepastian perlindungan dan kesejahteraan sosial bagi seluruh rakyat Indonesia.

\footnotetext{
10 Wawancara tanggal 20 Oktober 2017 dengan Eko Adi Sucipto Kasi HI Dinas Perindustrian Dan Ketenagakerjaan Kota Tarakan
} 
Penyelenggaraan jamianan sosial yang kuat dan berkelanjutan merupakan salah satu pilar negara kesejahteraan, disamping pilar lainnya, yaitu pendidikan bagi semua, lapangan pekerjaan yang terbuka luas dan pertumbuhan ekonomi yang stabil dan berkeadilan. Mengingat pentingnya peranan BPJS dalam menyelenggarakan program jaminan sosial dengan cakupan seluruh penduduk Indonesia, maka UU BPJS memberikan batasan fungsi, tugas dan wewenang yang jelas kepada BPJS. Dengan demikian dapat diketahui secara pasti batas-batas tanggung jawabnya dan sekaligus dapat dijadikan sarana untuk mengukur kinerja kedua BPJS tersebut secara transparan ${ }^{11}$

Perlindungan, pemeliharaan dan peningkatan kesejahteraan yang berbentuk program jaminan sosial ketenagakerjaan dicanangkan oleh pemerintah dan wajib dilaksanakan oleh pengusaha, apabila dalam pelaksanaannya telah memenuhi persyaratan yang telah di tentukan yaitu mempunyai pekerja sebanyak 10 (sepuluh) orang atau lebih dan juga mengeluarkan uang untuk menggaji pekerjanya sebesar 1.000.000 rupiah untuk setiap bulannya.

Pasal 15 ayat (1) UU BPJS telah mengatur tentang kewajiban pemberi kerja secara bertahap wajib mendaftarkan dirinya dan Pekerjanya sebagai Peserta kepada BPJS sesuai dengan program jaminan sosial yang diikuti. Ketentuan ini dipertegas kembali dalam Pasal 3 Ayat 1 Peraturan Pemerintah Republik Indonesia Nomor 86 Tahun 2013 tentang Tata Cara Pengenaan Sanksi Administratif Kepada Pemberi Kerja Selain Penyelenggara Negara dan Setiap Orang, Selain Pemberi Kerja, Pekerja, dan Penerima Bantuan Iuran Dalam Penyelenggaraan Jaminan Sosial selanjutnya disingkat PP 86 Tahun 2013 menyatakan bahwa pemberi kerja selain penyelenggara negara wajib:

a. Mendaftarkan dirinya dan pekerjanya sebagai peserta kepada BPJS secara bertahap sesuai dengan program jaminan sosial yang diikutinya; dan

b. Memberikan data dirinya dan pekerjanya berikut anggota keluarganya kepada BPJS secara lengkap dan benar.

Kewajiban pemberi kerja mendaftarkan pekerjanya sebagai peserta BPJS Ketenagakerjaan. Setiap pekerja yang bekerja dan menerima upah wajib diikut sertakan program BPJS oleh si pemberi kerja tanpa ada batasan mengenai jumlah pekerjanya. pekerja yang dimaksud adalah setiap orang yang bekerja menerima gaji, upah atau imbalan dalam bentuk lain (pasal 1 angka 11 UU SJSN) dan pemberi kerja adalah orang perseorangan, pengusaha, badan hukum, atau badan-badan lainnya yang mempekerjakan tenaga kerja atau penyelenggara negara yang mempekerjakan pegawai negeri dengan membayar gaji, upah, atau imbalan dalam bentuk lainnya (pasal 1 angka 12 UU SJSN).

\footnotetext{
${ }^{11}$ Asih Eka Putri, Seri Buku Saku - 2: Paham BPJS Badan Penyelenggara Jaminan Sosial ,Friedrich-EbertStiftung Kantor Perwakilan Indonesia, Jakarta, 2014, hal. 17
} 
Pasal 1 angka 5 UU Ketenagakerjaan memberikan pengertian pengusaha sebagai adalah:

a. Orang perseorangan, persekutuan, atau badan hukum yang menjalankan suatu perusahaan milik sendiri.

b. Orang perseorangan, persekutuan, atau badan hukum yang secara berdiri sendiri menjalankan perusahaan bukan miliknya;

c. Orang perseorangan, persekutuan, atau badan hukum yang berada di Indonesia mewakili perusahaan sebagaimana dimaksud dalam huruf a dan $b$ yang berkedudukan di luar wilayah Indonesia.

Jadi, perusahaan dalam bentuk persekutuan dengan karyawan di atas 20 orang itu termasuk pemberi kerja yang wajib mendaftarkan pekerjanya sebagai peserta BPJS Ketenagakerjaan. Pasal 14 UU BPJS pemberi kerja secara bertahap wajib mendaftarkan dirinya dan pekerjanya sebagai peserta kepada BPJS, sesuai dengan program jaminan sosial yang diikuti dan pekerja berhak untuk mendaftarkan diri sebagai peserta program jaminan sosial atas tanggungan pemberi kerja apabila pemberi kerja telah nyata-nyata tidak mendaftarkan pekerjanya pada BPJS.

Pasal 15 ayat (1) UU BPJS jo. Putusan Mahkamah Agung Nomor 82/PUU-X/2012 tentang persyaratan dan tata cara kepesertaan dalam program jaminan sosial ini diatur Peraturan Pemerintah Nomor 84 Tahun 2013 tentang Perubahan Kesembilan Atas Peraturan Pemerintah Nommor 14 tahun 1993 tentang Penyelenggaraan Program Jaminan Sosial tenaga Kerja selanjutnya disingkat PP No. 84 Tahun 2013. Dalam PP No. 84 Tahun 2013 ini antara lain disebutkan bahwa pengusaha yang mempekerjakan tenaga kerja sebanyak 10 orang atau lebih, atau membayar upah paling sedikit Rp 1 juta sebulan, wajib mengikutsertakan tenaga kerjanya dalam program jaminan sosial tenaga kerja (Pasal 2 ayat (3) PP No. 84 Tahun 2013.

Adapun sanksi bagi perusahaan jika perusahaan selain penyelenggara negara tidak melaksanakan kewajiban mendaftarkan pekerjanya sebagai peserta kepada BPJS adalah berupa sanksi administrasi.

Pengenaan sanksi tidak mendapat pelayanan publik tertentu dilakukan oleh unit pelayanan publik pada instansi Pemerintah, pemerintah daerah provinsi, atau pemerintah daerah kabupaten/kota diatur dalam Pasal 9 (3) PP No. 86 Tahun 2013.Pengenaan sanksi berupa teguran tertulis dan denda dilakukan oleh BPJS sebagaimana diatur dalam Pasal 17 ayat (3) UU BPJS. Selain itu, pemberi kerja juga mempunyai kewajiban untuk memungut iuran yang menjadi beban peserta dari pekerjanya dan menyetorkannya kepada BPJS dan wajib membayar serta menyetor iuran yang menjadi tanggung jawabnya kepada BPJS sebagaimana diatur dalam Pasal 19 ayat (1) dan (2) UU BPJS.

Pemberi kerja yang tidak mematuhi ketentuan dalam Pasal 19 ayat (1) dan (2) UU BPJS dapat dipidana dengan pidana penjara paling lama delapan tahun atau pidana denda paling banyak satu miliar rupiah. Pasal 18 UU SJSN. 
Terkait perusahaan diketahui belum mendaftarkan pekerjanya dalam program BPJS Ketenagakerjaan, maka Dinas Perindustrian dan Ketenagakerjaan Kota Tarakan dapat melapor ke kantor BPJS Ketenagakerjaan setempat, sehingga petugas dari kantor BPJS Ketenagakerjaan setempat dapat segera mengambil tindakan. Tindakan yang diambil oleh BPJS Ketenagakerjaan berupa teguran tertulis sebagaima dijelaskan dalam Pasal 6 ayat (1) Peraturan Pemerintah Nomor 86 Tahun 2013 tentang Tata Cara Pengenaan Sanksi Administratif Kepada Pemberi Kerja Selain Penyelenggara Negara dan Setiap Orang, Selain Pemberi Kerja, Pekerja, dan Penerima Bantuan Iuran dalam Penyelenggaraan Jaminan Sosial.

Program BPJS ketenagakerjaan menjadi solusi yang bijak dalam membantu perusahaan memenuhi kewajiban guna memberikan jaminan sosial bagi pekerja. Setiap perusahaan wajib memberikan jaminan sosial bagi pekerja dengan mengikutsertakannya program BPJS kesehatan dan BPJS ketenagakerjaan. Itu sudah diatur dan telah disediakan sanksi bagi perusahaan yang tidak melaksanakannya. Keuntungan pekerja ikut dalam program BPJS ketenagakerjaan para pekerja mendapat jaminan tunjangan di hari tua maupun kematian. Sedangkan perusahaan tidak lagi terbebani akan memberikan tunjangan pekerja ketika mengikutsertakan pekerja dalam program BPJS kesehatan dan ketenagakerjaan.

BPJS Ketenagakerjaan wajib bagi perusahaan terutama Badan Usaha Milik Negara (BUMN) dan Badan Usaha Milik Daerah (BUMD) mengenai keikutsertaan karyawan dalam program BPJS Ketenagakerjaan. Mendaftarkan dirinya dan pekerjanya sebagai peserta kepada BPJS secara bertahap sesuai dengan program jaminan sosial yang diikutinya dan memberikan data dirinya dan pekerjanya berikut anggota keluarganya kepada BPJS secara lengkap dan benar. Jika perusahaan tidak mengikutsertakan karyawannya maka terancam dikenai sanksi kurungan dan denda hingga miliaran rupiah. BPJS memiliki petugas pengawas dan pemeriksa yang akan memeriksa perusahaanperusahaan yang melanggar ketentuan Undang-Undang BPJS Ketenagakerjaan.

BPJS Ketenagakerjaan dalam hal ini mempunyai kewenangan untuk melakukan tindakan tersebut. Apabila sampai dengan berakhirnya jangka waktu yang telah ditentukan perusahaan tidak juga melaksanakan kewajibannya, maka pengawas BPJS Ketenagakerjaan akan mengenakan sanksi teguran tertulis untuk kedua kalinya dalam waktu yang telah ditentukan. Jika teguran kali kedua ini di masih di hiraukan oleh perusahaan, maka Dinas Perindustrian Dan Ketenagakerjaan Kota Tarakan dapat melaporkan perusahaan yang belum mendaftarkan pekerjanya dalam BPJS Ketenagakerjaan ke Kantor Perizinan untuk menjatuhkan sanksi administratif berupa tidak mendapatkan pelayanan publik tertentu salah satunya dengan pencabutan izin usaha atas permintaan BPJS Ketenagakerjaan setempat.

Selain sanksi administrasi sanksi pidana juga dapat di jatuhkan kepada pemberi kerja/pengusaha. UU Badan Penyelenggara Jaminan Sosial (BPJS) yang berlaku 1 Januari 2014 mewajibkan peserta membayar iuran dalam jumlah tertentu. Bila tidak membayarkan iuran wajib itu, dapat di kenakan sanksi pidana. Pembayar iuran atau premi BPJS menurut Pasal 19 UU tersebut adalah pemberi kerja, peserta yang bukan pekerja dan bukan penerima bantuan iuran wajib, dan pemerintah. Yang dimaksud 
pemberi kerja adalah orang perseorangan, pengusaha, badan hukum, atau badan lainnya yang mempekerjakan tenaga kerja atau penyelenggara negara yang mempekerjakan pegawai negeri dengan membayar gaji, upah, atau imbalan dalam bentuk lainnya. Berikut bunyi pasal pembayar iuran yang tercantum dalam Pasal 19 yang menyatakan:

1. Pemberi Kerja wajib memungut Iuran yang menjadi beban Peserta dari Pekerjanya dan menyetorkannya kepada BPJS.

2. Pemberi Kerja wajib membayar dan menyetor Iuran yang menjadi tanggung jawabnya kepada BPJS.

3. Peserta yang bukan Pekerja dan bukan penerima Bantuan Iuran wajib membayar dan menyetor Iuran yang menjadi tanggung jawabnya kepada BPJS.

4. Pemerintah membayar dan menyetor Iuran untuk penerima Bantuan Iuran kepada BPJS

5. Ketentuan

lebih

lanjut

mengenai:

a. besaran dan tata cara pembayaran Iuran program jaminan kesehatan diatur dalam Peraturan Presiden; dan b. besaran dan tata cara pembayaran Iuran selain program jaminan kesehatan diatur dalam Peraturan Pemerintah.

Ketentuanl sanksi dalam UU BPJS dikenakan hanya pada pemberi kerja saja jika lalai membayar iuran BPJS yakni pidana maksimal 8 tahun penjara atau denda maksimal Rp 1 miliar,sebagaimana tercantum dalam Pasal 55 yang menyatakan bahwa Pemberi Kerja yang melanggar ketentuan sebagaimana dimaksud dalam Pasal 19 ayat (1) atau ayat (2) dipidana dengan pidana penjara paling lama 8 (delapan) tahun atau pidana denda paling banyak Rp1.000.000.000,00 (satu miliar rupiah)

Dalam rangka penegakan sanksi administrasi dan pidana telah dibentuk Tim Forum Koordinasi Pengawasan dan Pemeriksaan Kepatuhan yang terdiri dari:

Penanggung Jawab : Kepala BPJS Ketenagakerjaan KC Tarakan

Ketua : Kepala Kejaksaan Negeri Tarakan

Sekretaris $\quad$ : Kepala BPJS Ketenagakerjaan KC Tarakan

Anggota

1. Kepala Dinas Penanaman Modal dan PTSP Kota Tarakan

2. Kepala Dinas Tenaga Kerja Kota Tarakan

3. Kasi Datun Kejaksaan Negeri Tarakan

4. Kabid HI Dinas Tenaga Kerja Kota Tarakan

5. Kasi HI Dinas Tenaga Kerja Kota Tarakan

6. Kabid Pemasaran BPJS Ketenagakerjaan KC Tarakan

7. Petugas Pemeriksa BPJS Ketenagakerjaan KC Tarakan

8. Adhoc

Adapun tugas Tim Forum Koordinasi Pengawasan dan Pemeriksaan Kepatuhan yaitu melakukan evaluasi atas pelaksanaan pengawasan dan pemeriksaan dalam rangka peningkatan cakupan kepesertaan kepatuhan pemberian data yang lengkap dan benar 
serta kepatuhan pembayaran iuran serta merumuskan strategi yang dapat di terapkan untuk meningkatkan kepatuhan pemberi kerja. 


\section{KESIMPULAN}

Berdasarkan hasil penelitian tentang pemenuhan hak atas jaminan sosial ketenagakerjaan di Kota Tarakan dapat disimpulkan berikut:

1. Kebijakan perusahaan dalam pemenuhan hak tenaga kerja atas jaminan sosial ketenagakerjaan di Kota Tarakan menunjukkan bahwa 9\% perusahaan telah memenuhi kewajibannya dengan medaptarkan diri dan pekerjanya pada program BPJS Ketenagakerjaan dan 91\% Perusahaan belum mendaptarkan diri dan pekerjanya pada program BPJS Ketenagakerjaan. di sebabkan karena pegawai yang berstatus tidak tetap dan keuangan perusahaan yang belum mencukupi untuk membayar iuran BPJS Ketenagakerjaan.

2. Faktor-faktor yang mempengaruhi tidak terlaksananya pemenuhan hak tenaga kerja atas jaminan sosial ketenagakerjaan di Kota Tarakan diantaranya usaha kecil/usaha baru, telah ikut asusransi swasta dan BPJS Kesehatan, kurangnya pemahaman tentang BPJS Kesehatan dan Ketenagakerjaan, pekerja tidak tetap/ pekerja kontrak dengan perjanjian dan pekerja tidak bersedia mengikuti Program BPJS Ketenagakerjaan.

3. Akibat hukum terhadap perusahaan dan tenaga kerja yang tidak terdaptar di BPJS Ketenagakerjaan adalah dikenakan sanksi administratif sebagaimana yang telah diatur dalam Peraturan Pemerintah (PP) No. 86 Tahun 2013 tentang Tata Cara Pengenaan Sanksi Administratif Kepada Pemberi Kerja Selain Penyelenggara Negara dan Setiap Orang, Selain Pemberi Kerja, Pekerja, dan Penerima Bantuan Iuran dalam Penyelenggaraan Jaminan Sosial hingga sanksi pidana.

\section{SARAN}

1. BPJS Ketenagakerjaan perlu meningkatkan kerjasama dengan instansi lainnya di Kota Tarakan dalam hal sosialisasi BPJS Ketenagakerjaan kepada para pemilik usaha/pemberi kerja tentang kewajiban perusahaan dalam memenuhi hak-hak pekerja serta konsekwensi hukumnya.

2. BPJS Ketenagakerjaan perlu melakukan singkronisasi data perusahaan dan tenaga kerja yang berdomisili di Kota Tarakan dengan instansi terkait untuk menjamin terpenuhinya hak-hak pekerja atas jaminan sosial ketenagakerjaan.

3. Penegakan hukum harus dilaksanakan sebaik-baiknya oleh Tim Forum Koordinasi Pengawasan dan Pemeriksaan Kepatuhan untuk memberikan efek jera kepada perusahaan yang tidak mendaptarkan tenaga kerjanya.

\section{DAFTAR BACAAN}

\section{A. Buku-Buku}

Abdul khakim, Pengantar Hukum Ketenagakerjaan Indonesia, Jakarta: Citra Aditya Bakti 2003.

Abdul Latif, Hukum dan Peraturan Kebijaksanaan (Beleidsregel) pada Pemerinthan Daerah,Cetakan I, UII Press, Yogyakarta, 2005 
Aris Ananta, Liberalisasi ekspor dan impor Tenaga Kerja suatu pemikiran awal, Pusat Penelitian Kependudukan UGM, 1996

Gouw Giok Siong, Pengertian Tentang Negara Hukum, Keng Po,Jakarta, 1955, Hardijan Rusli, Hukum Ketenagakerjaan. Ghalian Indonesia , Jakarta, 2003

Irfan Fachrudin, Pengawasan Peradilan Administrasi terhadap Tindakan pemerintah, Cetakan I, Alumni, Bandung, 2004

Lalu Husni, Pengantar Hukum Ketenagakerjaan, Ed-Revisi, Raja Grafindo Persada, Jakarta, 2014

Zainal Asikin, dkk, Dasar-Dasar Hukum Perburuhan, Cet 4, Raja Grafindo Persada, Jakarta, 2002.

Zaeni Asyhadie, Hukum Kerja (Hukum Ketenagakerjaan Bidang Hubungan Kerja), edisi revisi 2, PT.RajaGrafindo Persada, Jakarta, 2008.

Philipus M Hadjon, Pengkajian Ilmu Hukum Dogmatik (Normatif), Fakultas Hukum Universitas Airlangga, Surabaya, 1994.

-------------, Perlindungan Hukum Bagi Rakyat Indonesia, Bina Ilmu Surabaya, 1987

Rochmat Soemitro,Peradilan Administrasi Dalam Hukum Pajak Di Indonesia,Cetakan keIV,PT. ERESCO,Jakarta - Bandung,1976.

Satjipto Rahardjo, Pendayagunaan Sosiologi Hukum untuk Memahami Proses-proses dalam Konteks Pembangunan dan Globalisasi, Jurnal Hukum, No. 7 Vol. 4 Tahun 1997.

Soehino,Ilmu Negara,Cetakan III, Liberyty, Yogyakarta, 1998.

Satjipto Rahardjo, Ilmu Hukum, Bandung: PT. Citra Aditya Bakti, 2000.

Utrecht, Pengantar Hukum Administrasi Negara Indonesia, PT. Ichtiar, Jakarta, 1963.

\section{B. Peraturan Perundang-undangan}

Undang - Undang Nomor 13 Tahun 2003 Tentang Ketenagakerjaan

Undang - Undang Nomor 40 Tahun 2004 Tentang Sistem Jaminan Sosial Nasional

Undang - Undang Nomor 24 Tahun 2011 Tentang Badan Penyelenggara Jaminan Sosial

Peraturan Pemerintah Nomor 86 Tahun 2013 tentang Tata Cara Pengenaan Sanksi Administratif Kepada Pemberi Kerja Selain Penyelenggara Negara dan Setiap Orang, Selain Pemberi Kerja, Pekerja, dan Penerima Bantuan Iuran Dalam Penyelenggaraan Jaminan Sosial;

Peraturan Presiden Nomor 111 Tahun 2013 tentang Perubahan atas Peraturan Presiden Nomor 12 Tahun 2013 tentang Jaminan Kesehatan; 
Peraturan Menteri Kesehatan Nomor 71 Tahun 2013 tentang Pelayanan Kesehatan pada Jaminan Kesehatan Nasional.

Peraturan Presiden Nomor 109 Tahun 2013 Tentang Penahapan Kepesertaan Program Jaminan Sosial

Peraturan Gubernur Propinsi Kalimantan Utara Nomor 20 Tahun 2014 Tentang Jaminan Sosial Ketenagakerjaan

Instruksi Walikota Tarakan Nomor 1 Tahun 2015 tentang Penyelenggaraan Program BPJS Ketenagakerjaan Bagi Tenaga Kerja Harian Lepas,Borongan dan PKWT Pada Jasa Konstruksi Di Kota Tarakan 